\title{
Genetic Mapping of Stem Rust Resistance to Puccinia graminis f. sp. tritici Race TRTTF in the Canadian Wheat Cultivar Harvest
}

\author{
Colin W. Hiebert, Matthew N. Rouse, Jayaveeramuthu Nirmala, and Tom Fetch
}

First author: Agriculture and Agri-Food Canada, Morden Research and Development Centre, 100, Morden, MB R6M 1Y5, Canada; second and third authors: U.S. Department of Agriculture-Agricultural Research Service, Cereal Disease Laboratory and Department of Plant Pathology, University of Minnesota, St. Paul, MN 55108; and fourth author: Agriculture and Agri-Food Canada, Brandon Research and Development Centre, Brandon, MB R7A 5Y3, Canada.

Accepted for publication 28 September 2016.

\begin{abstract}
Stem rust, caused by Puccinia graminis f. sp. tritici, is a destructive disease of wheat that can be controlled by deploying effective stem rust resistance (Sr) genes. Highly virulent races of $P$. graminis f. sp. tritici in Africa have been detected and characterized. These include race TRTTF and the Ug99 group of races such as TTKSK. Several Canadian and U.S. spring wheat cultivars, including the widely grown Canadian cultivar 'Harvest', are resistant to TRTTF. However, the genetic basis of resistance to TRTTF in Canadian and U.S. spring wheat cultivars is unknown. The objectives of this study were to determine the number of $\mathrm{Sr}$ genes involved in TRTTF resistance in Harvest, genetically map the resistance with DNA markers, and use markers to assess the distribution of that resistance in a panel of Canadian cultivars. A doubled haploid (DH) population was produced from the cross LMPG-6S/Harvest. The DH population was tested with race TRTTF at the seedling stage. Of $92 \mathrm{DH}$ progeny evaluated,

46 were resistant and 46 were susceptible which perfectly fit a 1:1 ratio indicating a single $\mathrm{Sr}$ gene was responsible for conferring resistance to TRTTF in Harvest. Mapping with single nucleotide polymorphism (SNP) and simple sequence repeat (SSR) markers placed the resistance gene distally on the chromosome 6AS genetic map, which corresponded to the location reported for $\mathrm{Sr} 8$. SSR marker gwm459 and 30 cosegregating SNP markers showed the closest linkage, mapping $2.2 \mathrm{cM}$ proximal to the $\mathrm{Sr}$ gene. Gene $\mathrm{Sr} 8 \mathrm{a}$ confers resistance to TRTTF and may account for the resistance in Harvest. Testing a panel of Canadian wheat cultivars with four SNP markers closely linked to resistance to TRTTF suggested that the resistance present in Harvest is present in many Canadian cultivars. Two of these SNP markers were also predictive of TRTTF resistance in a panel of 241 spring wheat lines from the United States, Canada, and Mexico.
\end{abstract}

Stem rust, caused by the fungus Puccinia graminis Pers.:Pers. f. sp. tritici Eriks. \& E. Henn., is a destructive disease of wheat. In Canada, there have been severe epidemics of stem rust in the Prairies. For example, epidemics in the 1950 s destroyed up to $40 \%$ of the spring wheat crop in the North American plains (Peturson 1958). Since then, vigilant testing and selection of resistant breeding material and the removal of barberry (Berberis vulgaris L.), the alternate host of $P$. graminis f. sp. tritici, has prevented further epidemics in North America (Kolmer et al. 1991). However, in 1998 there was a new race of $P$. graminis f. sp. tritici (TTKSK, also known as Ug99) detected in Uganda that was virulent to stem rust resistance (Sr) gene $\mathrm{Sr} 31$ and most of the known Sr genes (Jin et al. 2007; Pretorius et al. 2000). Similarly, another highly virulent race (TRTTF) was found in Yemen in 2006 and subsequently in Ethiopia (Olivera et al. 2012). These virulent races of $P$. graminis f. sp. tritici represent a threat to wheat production as approximately $90 \%$ of the wheat cultivars grown globally are susceptible to Ug99-type races, and the frequency of virulence of TRTTF is high in both common and durum wheat.

A preliminary assessment of a panel of Canadian wheat cultivars showed that resistance to $\mathrm{Ug} 99$ was not widespread while resistance to TRTTF was more common. The resistance to Ug99 in Canadian wheat can be attributed to the presence of SrCad in several spring wheat cultivars (Hiebert et al. 2011). The reliance on a single gene for resistance to Ug99-type races leaves Canadian cultivars in a precarious

Corresponding author: C. W. Hiebert; E-mail address: colin.hiebert@agr.gc.ca

*The $e$-Xtra logo stands for "electronic extra" and indicates that two supplementary tables are published online.

Her Majesty the Queen in Right of Canada, as represented by the Minister of Agriculture and Agri-Food Canada, 2017 position in the event that $\mathrm{Ug} 99$ is introduced into North America. In contrast, the genetic basis for resistance to TRTTF in Canadian cultivars is unknown. Known genes that confer resistance to TRTTF include Sr8a, Sr22, Sr24, Sr26, Sr27, Sr31, Sr32, Sr33, Sr35, Sr39, $\mathrm{Sr} 40, \mathrm{Sr} 46, \mathrm{Sr} 47, \mathrm{Sr} 50$, and SrSatu (Olivera et al. 2012). Recently, resistance to TRTTF in a US hard red spring wheat line was mapped to chromosome arm 6AS and postulated to be $S r 8 a$ (Guerrero-Chavez et al. 2015). While many of the above Sr genes that confer resistance to $P$. graminis $\mathrm{f}$. $\mathrm{sp}$. tritici race TRTTF are very unlikely to be present in Canadian cultivars, it is possible that one or more of the above genes is present or perhaps unknown Sr gene(s) could be present.

The Canadian Western Red Spring (CWRS) is the most important class of Canadian bread wheat. The cultivar 'Harvest' ('AC Domain'*2/ND640) (Fox et al. 2010) is susceptible to Ug99 but resistant to TRTTF. In 2013, Harvest was sown on 1.5 million acres in Western Canada, more than any other CWRS wheat cultivar. There were several Canadian bread wheat cultivars identified as resistant to TRTTF in our preliminary tests, but Harvest was chosen for this study based on its economic importance. The goals of this study were to determine the inheritance of resistance to $P$. graminis f. sp. tritici race TRTTF in Harvest, to genetically map the resistance with DNA markers, and to assess a panel of Canadian varieties with DNA markers linked to gene(s) conditioning resistance to TRTTF in order to postulate the distribution of the resistance found in Harvest in other wheat cultivars.

\section{MATERIALS AND METHODS}

Plant material and stem rust testing. A set of 44 spring wheat cultivars were used for testing with $P$. graminis f. sp. tritici races TRTTF and Ug99 (TTKSK) at the seedling stage (Table 1). 
The cultivars were also genotyped with DNA markers linked to the resistance to TRTTF mapped in a Harvest-derived population to postulate the distribution of the resistance. Most of the cultivars were bred in Canada and all of them are currently or were previously grown commercially in the Canadian Prairies.

A cross was made between LMPG-6S ('Little Club'//'Prelude'*8/ 'Marquis'/3/'Gabo') and Harvest. LMPG-6S was developed as a stem rust susceptible line and kindly provided to us by the late D. R. Knott (University of Saskatchewan, Canada). The $F_{1}$ progeny from the LMPG-6S/Harvest cross were used to make a doubled haploid (DH) population. The DH population was produced using a maize pollination method followed by colchicine-induced chromosome doubling (Thomas et al. 1997). Single plants of each DH line were grown to maturity with all spikes bagged prior to anthesis. Selfed seed from each DH line was used for further testing.

The 44 entries included in the cultivar panel were inoculated after the first leaf had fully emerged. The cultivar panel was inoculated with $P$. graminis f. sp. tritici races TRTTF (isolate 07-YEM-38) and
TTKSK (Ug99; isolate SA31) inside a biocontainment facility at the Morden Research and Development Centre in Morden, MB. Inoculations were performed by suspending urediniospores in light mineral oil (Bayol 55, Imperial Oil Canada, Toronto, ON) and spraying the suspension onto the seedlings. Inoculated seedlings were incubated in a dew chamber for $16 \mathrm{~h}$ and then were dried slowly under light. Plants were transferred to growth chambers and grown at approximately $20^{\circ} \mathrm{C}$ with $16 \mathrm{~h}$ of light daily. Seedlings were rated for their infection types (IT) 14 days postinoculation following the 0 to 4 scale described by Stakman et al. (1962). ITs of 0 to 2 were classified as a resistant, while ITs of 3 to 4 were classified as susceptible.

DH lines and parents from the LMPG-6S/Harvest population were sown and maintained in a biocontainment facility at the University of Minnesota in St. Paul, MN, as described by Rouse et al. (2014). Seedlings of $92 \mathrm{DH}$ lines, the parental lines, and the North American stem rust differential set were inoculated with P. graminis f. sp. tritici race TRTTF (isolate 06YEM34-1) after the first leaf had fully emerged, following the procedures of Rouse

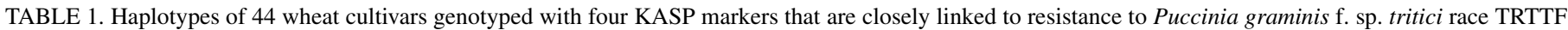
on chromosome 6AS

\begin{tabular}{|c|c|c|c|c|c|c|c|c|c|}
\hline \multirow[b]{2}{*}{ Cultivar } & \multicolumn{2}{|c|}{ TRTTF $^{\mathrm{a}}$} & \multicolumn{4}{|c|}{ KASP marker ${ }^{b}$} & \multicolumn{2}{|c|}{ TTKSK $^{\mathrm{a}}$} & \multirow[b]{2}{*}{ SrCad carrierc } \\
\hline & IT & Class & kwh53 & kwh54 & kwh55 & kwh57 & IT & Class & \\
\hline AC Abbey & 4 & $\mathrm{~S}$ & $\mathrm{~L}$ & $\mathrm{~L}$ & $\mathrm{~L}$ & $\mathrm{~L}$ & 4 & $\mathrm{~S}$ & \\
\hline AC Barrie & $33+$ & $\mathrm{S}$ & $\mathrm{L}$ & $\mathrm{L}$ & $\mathrm{L}$ & $\mathrm{L}$ & 4 & $\mathrm{~S}$ & \\
\hline AC Cadillac & $11-$ & $\mathrm{R}$ & $\mathrm{L}$ & $\mathrm{L}$ & $\mathrm{L}$ & $\mathrm{L}$ & $12-$ & $\mathrm{R}$ & $\mathrm{Y}$ \\
\hline AC Domain & $12-$ & $\mathrm{R}$ & $\mathrm{H}$ & $\mathrm{H}$ & $\mathrm{H}$ & $\mathrm{H}$ & $33+$ & $\mathrm{S}$ & \\
\hline AC Eatonia & $11+$ & $\mathrm{R}$ & $\mathrm{H}$ & $\mathrm{H}$ & $\mathrm{H}$ & $\mathrm{H}$ & 4 & $\mathrm{~S}$ & \\
\hline AC Elsa & $11-$ & $\mathrm{R}$ & $\mathrm{H}$ & $\mathrm{H}$ & $\mathrm{H}$ & $\mathrm{H}$ & $33+$ & $\mathrm{S}$ & \\
\hline AC Intrepid & $3+$ & $\mathrm{S}$ & $\mathrm{L}$ & $\mathrm{L}$ & $\mathrm{L}$ & $\mathrm{L}$ & 4 & $\mathrm{~S}$ & \\
\hline AC Karma & $1+$ & $\mathrm{R}$ & $\mathrm{L}$ & $\mathrm{L}$ & $\mathrm{L}$ & $\mathrm{L}$ & $2-$ & $\mathrm{R}$ & $\mathrm{Y}$ \\
\hline AC Majestic & 12 & $\mathrm{R}$ & $\mathrm{H}$ & $\mathrm{H}$ & $\mathrm{H}$ & $\mathrm{H}$ & 34 & $\mathrm{~S}$ & \\
\hline AC Michael & $3+$ & $\mathrm{S}$ & $\mathrm{L}$ & $\mathrm{L}$ & $\mathrm{L}$ & $\mathrm{L}$ & 34 & $\mathrm{~S}$ & \\
\hline AC Splendor & $3+$ & $\mathrm{S}$ & $\mathrm{L}$ & $\mathrm{L}$ & $\mathrm{L}$ & $\mathrm{L}$ & - & - & \\
\hline AC Taber & $12-$ & $\mathrm{R}$ & $\mathrm{H}$ & $\mathrm{H}$ & $\mathrm{H}$ & $\mathrm{H}$ & $2-$ & $\mathrm{R}$ & $\mathrm{Y}$ \\
\hline AC Vista & $12-$ & $\mathrm{R}$ & $\mathrm{L}$ & $\mathrm{L}$ & $\mathrm{L}$ & $\mathrm{L}$ & $12-$ & $\mathrm{R}$ & $\mathrm{Y}$ \\
\hline Bluesky & $1-$ & $\mathrm{R}$ & $\mathrm{H}$ & $\mathrm{H}$ & $\mathrm{H}$ & $\mathrm{H}$ & 34 & $\mathrm{~S}$ & \\
\hline Burnside & $3+$ & $\mathrm{S}$ & $\mathrm{L}$ & $\mathrm{L}$ & $\mathrm{L}$ & $\mathrm{L}$ & 34 & $\mathrm{~S}$ & \\
\hline Canthatch & $3+$ & $\mathrm{S}$ & $\mathrm{L}$ & $\mathrm{L}$ & $\mathrm{L}$ & $\mathrm{L}$ & 34 & $\mathrm{~S}$ & \\
\hline CDC Rama & $; 1$ & $\mathrm{R}$ & $\mathrm{H}$ & $\mathrm{H}$ & $\mathrm{H}$ & $\mathrm{H}$ & 4 & $\mathrm{~S}$ & \\
\hline CDC Teal & $3+$ & $\mathrm{S}$ & $\mathrm{L}$ & $\mathrm{L}$ & $\mathrm{L}$ & $\mathrm{L}$ & 4 & $\mathrm{~S}$ & \\
\hline CDC Walrus & $3+$ & $\mathrm{S}$ & $\mathrm{L}$ & $\mathrm{L}$ & $\mathrm{L}$ & $\mathrm{L}$ & 4 & $\mathrm{~S}$ & \\
\hline Glenavon & $3+$ & $\mathrm{S}$ & $\mathrm{L}$ & $\mathrm{L}$ & $\mathrm{L}$ & $\mathrm{L}$ & $3+$ & $\mathrm{S}$ & \\
\hline Glenlea & $3+$ & $\mathrm{S}$ & $\mathrm{L}$ & $\mathrm{L}$ & $\mathrm{L}$ & $\mathrm{L}$ & 4 & $\mathrm{~S}$ & \\
\hline Grandin & $33+$ & $\mathrm{S}$ & $\mathrm{L}$ & $\mathrm{L}$ & $\mathrm{L}$ & $\mathrm{L}$ & 4 & $\mathrm{~S}$ & \\
\hline Harvest & $; 1$ & $\mathrm{R}$ & $\mathrm{H}$ & $\mathrm{H}$ & $\mathrm{H}$ & $\mathrm{H}$ & $33+$ & $\mathrm{S}$ & \\
\hline Helios & 12 & $\mathrm{R}$ & $\mathrm{H}$ & $\mathrm{H}$ & $\mathrm{H}$ & $\mathrm{H}$ & $33+$ & $\mathrm{S}$ & \\
\hline Infinity & $; 1$ & $\mathrm{R}$ & $\mathrm{H}$ & $\mathrm{H}$ & $\mathrm{H}$ & $\mathrm{H}$ & $33+$ & $\mathrm{S}$ & \\
\hline Kanata & $12-$ & $\mathrm{R}$ & $\mathrm{H}$ & $\mathrm{H}$ & $\mathrm{H}$ & $\mathrm{H}$ & 4 & $\mathrm{~S}$ & \\
\hline Kane & $3+$ & $\mathrm{S}$ & $\mathrm{L}$ & $\mathrm{L}$ & $\mathrm{L}$ & $\mathrm{L}$ & 34 & $\mathrm{~S}$ & \\
\hline Katepwa & 34 & $\mathrm{~S}$ & $\mathrm{~L}$ & $\mathrm{~L}$ & $\mathrm{~L}$ & $\mathrm{~L}$ & 4 & $\mathrm{~S}$ & \\
\hline Laura & $11+$ & $\mathrm{R}$ & $\mathrm{H}$ & $\mathrm{H}$ & $\mathrm{H}$ & $\mathrm{H}$ & 34 & $\mathrm{~S}$ & \\
\hline Lillian & ;2- & $\mathrm{R}$ & $\mathrm{H}$ & $\mathrm{H}$ & $\mathrm{H}$ & $\mathrm{H}$ & 34 & $\mathrm{~S}$ & \\
\hline Lovitt & 12 & $\mathrm{R}$ & $\mathrm{H}$ & $\mathrm{H}$ & $\mathrm{H}$ & $\mathrm{H}$ & 34 & $\mathrm{~S}$ & \\
\hline Manitou & 34 & $\mathrm{~S}$ & $\mathrm{~L}$ & $\mathrm{~L}$ & $\mathrm{~L}$ & $\mathrm{~L}$ & 4 & $\mathrm{~S}$ & \\
\hline McKenzie & 34 & $\mathrm{~S}$ & $\mathrm{~L}$ & $\mathrm{~L}$ & $\mathrm{~L}$ & $\mathrm{~L}$ & 4 & $\mathrm{~S}$ & \\
\hline Neepawa & 34 & $\mathrm{~S}$ & $\mathrm{~L}$ & $\mathrm{~L}$ & $\mathrm{~L}$ & $\mathrm{~L}$ & 34 & $\mathrm{~S}$ & \\
\hline Pasqua & $1+$ & $\mathrm{R}$ & $\mathrm{H}$ & $\mathrm{H}$ & $\mathrm{H}$ & $\mathrm{H}$ & - & - & \\
\hline Peace & $; 1$ & $\mathrm{R}$ & $\mathrm{L}$ & $\mathrm{H}$ & $\mathrm{H}$ & $\mathrm{H}$ & $12-$ & $\mathrm{R}$ & $\mathrm{Y}$ \\
\hline Prodigy & $3+$ & $\mathrm{S}$ & $\mathrm{L}$ & $\mathrm{L}$ & $\mathrm{L}$ & $\mathrm{L}$ & 34 & $\mathrm{~S}$ & \\
\hline Redman & 4 & $\mathrm{~S}$ & $\mathrm{~L}$ & $\mathrm{~L}$ & $\mathrm{~L}$ & $\mathrm{~L}$ & 4 & $\mathrm{~S}$ & \\
\hline Roblin & 4 & $\mathrm{~S}$ & $\mathrm{~L}$ & $\mathrm{~L}$ & $\mathrm{~L}$ & $\mathrm{~L}$ & 34 & $\mathrm{~S}$ & \\
\hline Sinton & $3+$ & $\mathrm{S}$ & $\mathrm{L}$ & $\mathrm{L}$ & $\mathrm{L}$ & $\mathrm{L}$ & 34 & $\mathrm{~S}$ & \\
\hline Snowbird & ;1+ & $\mathrm{R}$ & $\mathrm{H}$ & $\mathrm{H}$ & $\mathrm{H}$ & $\mathrm{H}$ & 34 & $\mathrm{~S}$ & \\
\hline Stettler & $3+$ & $\mathrm{S}$ & $\mathrm{L}$ & $\mathrm{L}$ & $\mathrm{L}$ & $\mathrm{L}$ & 4 & $\mathrm{~S}$ & \\
\hline Thatcher & $3+$ & $\mathrm{S}$ & $\mathrm{L}$ & $\mathrm{L}$ & $\mathrm{L}$ & $\mathrm{L}$ & 34 & $\mathrm{~S}$ & \\
\hline Waskada & $2-$ & $\mathrm{R}$ & $\mathrm{H}$ & $\mathrm{H}$ & $\mathrm{H}$ & $\mathrm{H}$ & 4 & $\mathrm{~S}$ & \\
\hline
\end{tabular}

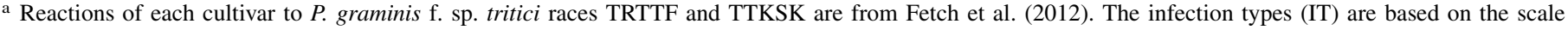
described by Stakman et al. (1962) with ITs of 2 or less classified as resistant (R) and ITs of 3 or greater classified as susceptible (S).

b A marker score of $\mathrm{H}$ indicates the same allele as 'Harvest' and L indicates the LMPG-6S allele.

c Y indicates known carriers of SrCad, based on Hiebert et al. (2011). 
et al. (2011), and were tested in two replicates. Fourteen days after inoculation the seedlings were evaluated for their IT using the scale described above. The ITs on Harvest were higher under the conditions in St. Paul so an IT of $2^{+} 3^{-}$was classified as resistant response and ITs of $3^{+}$was classified as a susceptible response. The ratio of resistant to susceptible plants was tested against expected genetic segregation ratios using $\chi^{2}$ goodness-to-fit tests.

DNA marker testing and genetic mapping. Young leaf tissue was collected from each line in the DH population and the parental lines. The tissue was lyophilized and then macerated. DNA was extracted from the macerated leaf tissue using the Qiagen DNeasy 96 Plant Kit following the manufacturer's protocol (Qiagen). The DH population and the parental lines were genotyped with a custom $90 \mathrm{~K}$ iSelect single nucleotide polymorphism (SNP) genotyping assay (Wang et al. 2014) following the manufacturers protocols (Illumina Inc., San Diego, CA). SNP alleles were called using GenomeStudio (Illumina Inc.) and filtered based on polymorphism between the parental lines. To simplify the data set, the two-point linkage recombination fraction was calculated between each marker and the phenotype (single gene segregation, see results). Markers with a recombination fraction equal or less than 0.30 were used for linkage mapping. A chromosome location for the resistance was determined by using the mapped locations of the SNP markers reported on the consensus map constructed with the $90 \mathrm{~K}$ iSelect SNPs (Wang et al. 2014). To confirm the chromosome location, the six terminal simple sequence repeat (SSR) markers from an improved version of the consensus map of chromosome arm 6AS reported by Somers et al. (2004) were tested for polymorphism between LMPG6S and Harvest (Röder et al. 1998; Somers et al. 2004; Sourdille et al. 2004). Polymorphic SSR markers were used to genotype the DH population. PCR amplification of SSR markers and fragment analysis using an ABI 3100 genetic analyzer (Applied Biosystems, Streetsville, ON) were performed as described by Somers et al. (2004). A genetic map of the chromosome region carrying resistance to $P$. graminis $\mathrm{f}$. sp. tritici race TRTTF was constructed using MapDisto (Lorieux 2012) and genetic distances were calculated using the Kosambi mapping function (Kosambi 1943).

SNP markers from the 90k iSelect array that mapped near the locus conferring resistance to race TRTTF were converted to Kompetitive allele-specific PCR (KASP) markers (Allen et al. 2011). DNA was extracted from 44 of the wheat cultivars that were tested for resistance to TRTTF and Ug99 following the above procedures. KASP assays were performed in 384-well PCR plates with a final reaction volume of $5 \mu \mathrm{l}$ containing $2.5 \mu \mathrm{l}$ of KASP $2 \times$ reaction mix (LGC Genomics), $0.07 \mu \mathrm{l}$ of assay mix (containing $12 \mu \mathrm{M}$ of each allelespecific forward primer, $30 \mu \mathrm{M}$ reverse primer and $46 \mu \mathrm{l}$ of TRIS [10mM, pH 8.3]), and $37.5 \mathrm{ng}$ of genomic DNA. The following PCR conditions were used: $15 \mathrm{~min}$ at $94^{\circ} \mathrm{C} ; 10$ touchdown cycles of $20 \mathrm{~s}$ at $94^{\circ} \mathrm{C}, 60 \mathrm{~s}$ at $61^{\circ} \mathrm{C}$ (dropping $0.6^{\circ} \mathrm{C}$ per cycle to $55^{\circ} \mathrm{C}$ ) and 26 cycles of $20 \mathrm{~s}$ at $94^{\circ} \mathrm{C}, 60 \mathrm{~s}$ at $57^{\circ} \mathrm{C}$. An Omega Fluorostar plate reader (BMG LABTECH GmbH, Ortenberg, Germany) was used for fluorescence detection of the PCR product. KASP data were analyzed using KlusterCaller software (LGC Genomics, Beverly). Marker haplotypes were compared across these lines to postulate if the resistance found in Harvest to race TRTTF is present in other Canadian varieties.

\section{RESULTS}

Stem rust testing. Out of the 44 cultivars tested with $P$. graminis f. sp. tritici race TRTTF there were 21 with ITs classified as resistant and 23 with ITs classified as susceptible. This set of cultivars was also inoculated with TTKSK (Ug99) and five were resistant while 37 were susceptible (Table 1). All of the cultivars that were resistant to $P$. graminis $\mathrm{f}$. $\mathrm{sp}$. tritici race TTKSK were also resistant to TRTTF. Harvest was resistant to TRTTF but susceptible to TTKSK and was chosen for a genetic study to analyze resistance to TRTTF.

Both the parents and the DH population were tested in two replicates with $P$. graminis $\mathrm{f}$. sp. tritici race TRTTF. The infection type of Harvest was $2^{+} 3^{-}$, whereas LMPG-6S showed an IT of $3^{+}$in both replications. The resistant DH lines showed low ITs similar to that of Harvest and susceptible DH lines showed high ITs similar to that of LMPG-6S and there were no discrepancies in the IT for each DH line between replicates. The $S r 8 a$ single-gene differential line 'ISr8a-Ra' displayed IT 2+3- in response to race TRTTF. There were 46 resistant and 46 susceptible DH lines, which perfectly fit a 1:1 single gene segregation ratio $(P=1.00)$. Harvest displayed IT $; 1$ in response to TRTTF in the Canadian cultivar panel seedling test (Table 1), whereas Harvest diplayed IT $2^{+} 3^{-}$in the mapping experiment. This difference may be due to the two assays being completed in different laboratories with different environmental conditions.

DNA marker testing and genetic mapping. There were 121 SNP markers that showed linkage to the single gene conferring resistance to TRTTF in the LMPG-6S/Harvest DH population as determined by two-point recombination fractions. Preliminary linkage mapping showed that many SNP markers cosegregated and could be grouped into 16 linkage bins. One SNP marker per linkage bin was used to represent the markers in that bin for constructing a linkage map (Supplementary Table S1). Comparing the markers linked to TRTTF resistance to the consensus map (Wang et al. 2014) showed that most of the markers had been mapped to the short arm of chromosome 6A. Comparing the preliminary genetic map with the highly curated genetic map from Cabral et al. (2014) suggested that the Sr gene conferring resistance to TRTTF in Harvest was terminal on 6AS and was assigned the temporary designation $S r_{-} T R T T F$. To help anchor the genetic map of $S r_{-} T R T T F$, SSR markers on 6AS (gpw3041, gpw4032, gpw2295, gpw4329, gwm334, and gwm459) were tested for polymorphism between Harvest and LMPG-6S, and polymorphic markers were tested for linkage to stem rust resistance in the DH population. Two SSR markers, gwm459 and gwm334, were polymorphic and showed linkage to the resistance gene. The data for the SNP and SSR markers were combined and used to construct a linkage map (Fig. 1). The SNP linkage bin represented by wsnp_Ra_c3996_7334169 cosegregated with the SSR marker gwm459 and showed the closest linkage with a genetic distance of 2.2 cM proximal to $S r_{-} T R T T F$ (Fig. 1). The nearest linkage bin included 30 SNP markers. The next closest bin of SNP markers, represented by RFL_Contig5170_330, mapped $3.3 \mathrm{cM}$ from the $\mathrm{Sr}$ gene and included 11 SNP markers. Unfortunately, no markers mapped distal to the $\mathrm{Sr}$ gene. The linkage map showed good colinearity with the genetic map of the distal region of chromosome arm 6AS constructed by Cabral et al. (2014) (Fig. 1).

KASP markers kwh53, kwh54, kwh55, and kwh57 were developed from SNP markers on the 90k iSelect SNP array that mapped to the linkage bin nearest to the Sr gene conferring resistance to $P$. graminis f. sp. tritici race TRTTF (Table 2). The KASP markers were used to genotype the 44 cultivars that were tested with P. graminis f. sp. tritici races TRTTF and TTKSK. SNP alleles were classified as either being like Harvest or like LMPG-6S. Nearly all of the cultivars that were resistant to TRTTF also carried Harvest alleles for all four of the KASP markers (Table 1). The resistant cultivars that carried LMPG-6S SNP alleles for all four KASP markers, 'AC Cadillac', 'AC Karma', and 'AC Vista', are all known to carry SrCad, a gene that confers resistance to TTKSK (Hiebert et al. 2011). All of the cultivars that were susceptible to TRTTF had LMPG-6S alleles for the KASP markers. 'Peace' was the only cultivar to show a nonuniform haplotype. One marker had the LMPG-6S allele and the other three markers had Harvest alleles. Peace is resistant to both TRTTF and TTKSK and carries SrCad (Table 1) (Hiebert et al. 2011).

\section{DISCUSSION}

As global P. graminis f. sp. tritici populations evolve races with increasing virulence to currently deployed genes, it is important to assess current germplasm for resistance to new races, determine which genes are present in cultivars and breeding material, and proactively diversify resistance to $P$. graminis $\mathrm{f}$. sp. tritici in 
breeding programs. For example, Canadian bread wheat cultivars have been assessed for reaction to Ug99 and it appears that resistance is conferred by one major gene $(\mathrm{SrCad})$ in all instances (Fetch et al. 2012; Hiebert et al. 2011). This has prompted prebreeding efforts to combine effective but previously undeployed $\mathrm{Sr}$ genes into elite Canadian germplasm so that breeders can more easily introduce new $\mathrm{Sr}$ gene combinations into their breeding programs. However, since the breeding focus has been on the Ug99type stem rust pathogen races, there has been a lag in studying resistance in Canadian germplasm to other virulent $P$. graminis $\mathrm{f}$. sp. tritici races such as TRTTF. Our data showed that resistance to TRTTF occurs at a higher frequency in Canadian wheat cultivars compared with resistance to Ug99. The genetic basis of this resistance was unknown; thus, Harvest was chosen as a starting point for assessing resistance to TRTTF.

Resistance to $P$. graminis f. sp. tritici race TRTTF in Harvest was conferred by a single gene that mapped distally on chromosome arm 6AS, and Sr_TRTTF was the terminal locus of the genetic map (Fig. 1). The only designated $\mathrm{Sr}$ gene on chromosome arm 6AS is $\mathrm{Sr} 8$ (McIntosh 1972). There have been two alleles ( $\mathrm{Sr} 8 a$ and $\mathrm{Sr} 8 b$ ) identified at the Sr8 locus (Singh and McIntosh 1986). Of these two, $\mathrm{Sr} 8 \mathrm{a}$ is known to confer resistance to race TRTTF (Olivera et al. 2012) while the reaction of $S r 8 b$ to race TRTTF is either unknown or unpublished. In the South Dakotan wheat line SD4279, resistance to TRTTF was also mapped to chromosome 6AS (Guerrero-Chavez et al. 2015). In that study, the 9k iSelect SNP array (Cavanagh et al. 2013) was used to map stem rust resistance, whereas the $90 \mathrm{k}$ iSelect SNP array (Wang et al. 2014) was used in the present study. The two SNP arrays do not share many markers, however our map has two markers in common with the map presented by Guerrero-Chavez et al. (2015). In both maps, marker wsnp_Ra_c39996_7334169, along with different cosegregating SNPs (i.e., this was the only SNP marker in common within each map's respective linkage bins), was the closest marker to the Sr gene on chromosome 6AS with a genetic distance of $1.83 \mathrm{cM}$ in the Guerrero-Chavez et al. (2015) map and $2.2 \mathrm{cM}$ in our map (Fig. 1). It is likely that Harvest and SD4279 carry the same gene for resistance to race TRTTF. Based on the map position and stem rust reaction, Guerrero-Chavez et al. (2015) postulated that the resistance gene to race TRTTF on 6AS was $\mathrm{Sr} 8 \mathrm{a}$. There is one previous genetic study that reportedly mapped the $\mathrm{Sr} 8$

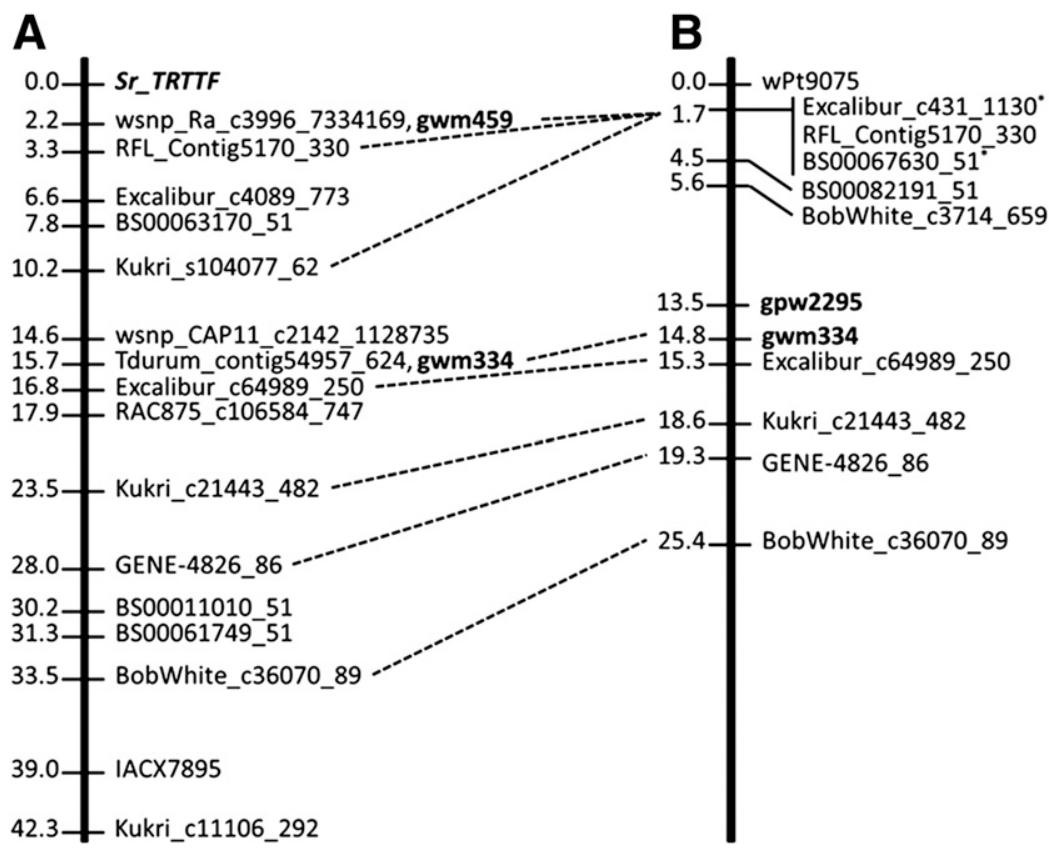

Fig. 1. A, Genetic map of TRTTF resistance in the LMPG-6S/'Harvest' doubled haploid population using single nucleotide polymorphism (SNP) and simple sequence repeat (SSR) markers. B, Genetic map of chromosome arm 6AS from the RL4452/'AC Domain' population by Cabral et al. (2014) to compare the map order in the LMPG-6S/Harvest map. SSR markers and the phenotype are shown in boldface in the LMPG-6S/Harvest map. A single SNP marker is shown to represent each linkage bin. Genetic distances in centiMorgans. *The SNP marker Excalibur_c431_1130 cosegregated with wsnp_Ra_c3996_7334169 and BS00067630_51 cosegregated with Kukri_s104077_62 in the LMPG-6S/Harvest population.

TABLE 2. Kompetitive allele-specific PCR (KASP) markers derived from 90k iSelect single nucleotide polymorphism markers on chromosome 6AS that mapped $2.2 \mathrm{cM}$ from the resistance to Puccinia graminis f. sp. tritici race TRTTF in the cultivar Harvest

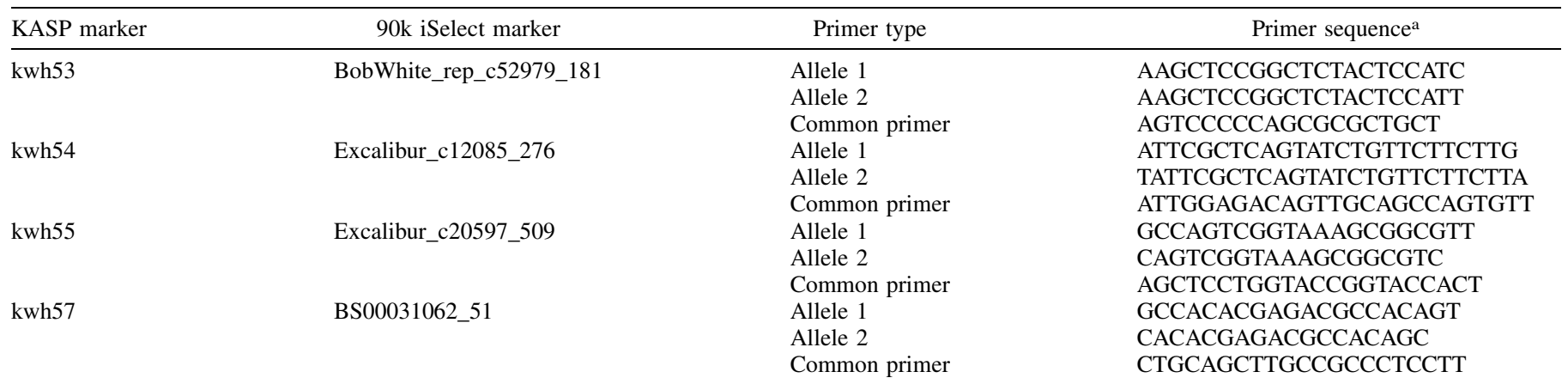

${ }^{\text {a }}$ KASP allele-specific primers require $5^{\prime}$ tails: FAM in the allele 1 primers and VIC in the alternate allele 2 primers. These are provided by LCG Genomics, the manufacturer of KASP reagents. 
locus (Bhavani et al. 2008). In that study, the authors conclude that they mapped $S r 8 b$ in a durum population. The maps presented by Guerrero-Chavez et al. (2015) and Bhavani et al. (2008) have no markers in common. However, our genetic map of the LMPG-6S/ Harvest population includes the SSR marker gwm334, which was also used to map $\operatorname{Sr} 8 b$ (Bhavani et al. 2008). In both cases the Sr gene maps near gwm334, which supports the hypothesis that the resistance mapped in Harvest and in SD4279 could be an allele of Sr8. Unfortunately, Bhavani et al. (2008) only found a single marker (gwm334) that was linked with the gene they reported as $S r 8 b$. Thus, it is not possible to determine whether $S r 8 b$ mapped distally or proximally to gwm334. To have a better assessment of the map position of $S r 8$, it would be useful to map $S r 8$ with the SNP and SSR markers used in the present study in a mapping population where the resistant parent is a single-gene reference stock of $\operatorname{Sr} 8$. A saturated genetic map of $S r 8$ that uses multiple marker types would better facilitate comparisons between genetic maps.

The resistance to $P$. graminis $\mathrm{f}$. sp. tritici race TRTTF in Canadian cultivars has not been previously studied. While mapping in the LMPG-6S/Harvest DH population demonstrated that an Sr gene, possibly $\mathrm{Sr} 8$, on chromosome arm 6AS is responsible for resistance to TRTTF in Harvest, it is useful to understand the basis for resistance in other cultivars as well. Genotyping the panel of 44 cultivars that have known responses to TRTTF with the four KASP markers suggested that the resistance on chromosome 6AS is common among Canadian cultivars resistant to TRTTF (Table 1). Of the 21 cultivars that were resistant to race TRTTF, 17 had the same alleles as Harvest for the four KASP markers. Three cultivars were resistant to TRTTF but had the same haplotype as LMPG-6S. These cultivars all carry $\mathrm{SrCad}$ which confers resistance to Ug99 races of $P$. graminis f. sp. tritici (Hiebert et al. 2011). One cultivar, Peace, did not have a haplotype that was uniformly Harvest alleles or LMPG-6S alleles (Table 2). Peace was resistant to TRTTF and is a carrier of $\mathrm{SrCad}$ (Hiebert et al. 2011). If Peace does carry Sr_TRTTF on chromosome arm 6AS then the haplotype suggests the SNP marker kwh53 is further from Sr_TRTTF than the other three markers. Conversely, if Peace lacks $S r_{-} T R T T F$ the haplotype suggests that kwh53 is the nearest marker to the gene.

The data suggest that $\operatorname{Sr} 8$ may be present in many Canadian cultivars and confers resistance to TRTTF. One possible explanation of the source of this resistance is from the line breeding RL4137, which has been used to provide sprouting resistance in Canadian wheat. Line RL4137 is in the pedigree of AC Domain (a parent of Harvest) and has the cultivar 'Frontana' in its pedigree. Frontana carries genes $\mathrm{Sr} 8 a$ and $\mathrm{Sr} 9 b$ (Knott and Shen 1961); thus, it is postulated that Canadian wheat cultivars could have inherited Sr8a from Frontana through RL4137. Hiebert et al. (2016) demonstrated that $S r C a d$ confers resistance to $P$. graminis f. sp. tritici race TRTTF. This is consistent with the data presented here as all of the cultivars carrying SrCad were resistant to TRTTF, but most of these lines did not possess the Harvest alleles of the SNP markers of chromosome arm 6AS (Table 1). While the assessment of the 44 Canadian cultivars suggest that $\mathrm{Sr} 8$ and $\mathrm{SrCad}$ are involved in resistance to TRTTF, we cannot exclude the presence of additional $\mathrm{Sr}$ genes in Canadian cultivars that could also contribute to TRTTF resistance without conducting additional genetic studies.

Bajgain et al. (2015) reported the association of 18 SNPs (with $P$ values less than $1.0 \times 10^{-12}$ ) on chromosome arm 6 AS with resistance to race TRTTF in a panel of 241 North American cultivars and breeding lines. All 18 of these SNPs were also detected in the LMPG-6S/Harvest linkage groups at distances 2.2 or $3.3 \mathrm{cM}$ proximal to Sr_TRTTF. We downloaded the data for these 18 markers from the Triticeae Coordinated Agricultural Project website (https://triticeaetoolbox.org/) and displayed these data in Supplementary Table S2. A total of 100 lines displayed the Harvest allele TT for marker Excalibur_c12085_276 that corresponded to KASP marker kwh54 in our study, whereas 140 lines displayed allele CC. SD4279 and Harvest were included in this panel and both were resistant to race TRTTF and displayed the Harvest TT allele. Out of the 100 lines with the Harvest allele, 73 were resistant to race TRTTF, 13 were susceptible, and 14 displayed heterogeneous or inconsistent responses. The majority of the 13 susceptible lines were from breeding programs in the Western United States and CIMMYT. Three of these lines (including the one line from Canada) displayed marker haplotypes with the Harvest allele for at least 6 of the other 17 markers linked to Sr_TRTTF. For the 140 lines with the CC allele for marker Excalibur_c12085_276, 107 were susceptible to race TRTTF, 15 were resistant, and 18 displayed heterogeneous or inconsistent responses. The 15 resistant lines included $\mathrm{SrCad}$ carriers AC Cadillac, AC Karma, and AC Vista. The data from this association mapping study validate the association of our markers in diverse germplasm from Canada and the United States and reveal lines with exceptions to the marker-trait association. These exceptions could be due to the presence of genes effective to race TRTTF other than $S r_{-} T R T T F$ and due to recombination between $S r_{-} T R T T F$ and associated markers. This underscores the need for more predictive markers however the markers presented here should be effective for marker-assisted selection (MAS) provided that there is adequate knowledge about the germplasm.

In conclusion, we have shown that a single $\mathrm{Sr}$ gene on chromosome 6AS is responsible for resistance to $P$. graminis $\mathrm{f}$. sp. tritici race TRTTF in the cultivar Harvest. This resistance could be conferred by gene $\mathrm{Sr} 8$. KASP markers were developed for this resistance that will enable marker-assisted breeding. Finally, a survey of Canadian wheat cultivars showed a strong association between resistance to TRTTF and the presence of Harvest alleles of KASP markers on chromosome 6AS suggesting that $S r_{-} T R T T F$ is largely responsible for resistance to TRTTF in Canadian cultivars. The development of more predictive markers would allow broader application of MAS to enhance resistance to $P$. graminis f. sp. tritici race TRTTF in wheat breeding programs.

\section{ACKNOWLEDGMENTS}

We thank M. Popovic, G. Mardli, T. Zegeye, S. Stoxen, T. Malasiuk, and E. Martineau for excellent technical assistance. M. Rouse acknowledges funding from USDA-ARS appropriated project 5062-21220-021-00, the USDA-ARS National Plant Disease Recovery System, and the Durable Rust Resistance in Wheat Project. C Hiebert and T. Fetch acknowledge funding from Agriculture and Agri-Food Canada Growing Forward.

\section{LITERATURE CITED}

Allen, A. M., Barker, G. L. A., Berry, S. T., Coghill, J. A., Gwilliam, R., Kirby, S., Robinson, P., Brenchley, R. C., D’Amore, R., McKenzie, N., Waite, D., Hall, A., Bevan, M., Hall, N., and Edwards, K. J. 2011. Transcript-specific, single-nucleotide polymorphism discovery and linkage analysis in hexaploid bread wheat (Triticum aestivum L.). Plant Biotechnol. J. 9:1086-1099.

Bajgain, P., Rouse, M. N., Bulli, P., Bhavani, S., Gordon, T., Wanyera, R., Njau, P. N., Legesse, W., Anderson, A. J., and Pumphrey, M. O. 2015. Association mapping of North American spring wheat breeding germplasm reveals loci conferring resistance to Ug99. BMC Plant Biol. 15:249.

Bhavani, S., Bansal, U. K., Hare, R., and Bariana, H. S. 2008. Genetic mapping of stem rust resistance in durum wheat cultivar 'Arrivato'. Int. J. Plant Breed. 2:23-26.

Cabral, A. L., Jordan, M. C., McCartney, C. A., You, F. M., Humphreys, D. G., MacLachlan, R., and Pozniak, C. J. 2014. Identification of candidate genes, regions and markers for pre-harvest sprouting resistance in wheat (Triticum aestivum L.). BMC Plant Biol. 14:340.

Cavanagh, C. R., Chao, S., Wang, S., Huang, B. E., Stephen, S., Kiani, S., Forrest, K., Saintenac, C., Brown-Guedira, G. L., Akhunova, A., See, D., Bai, G., Pumphrey, M., Tomar, L., Wong, D., Kong, S., Reynolds, M., da Silva, M. L., Bockelman, H., Talbert, L., Anderson, J. A., Dreisigacker, S., Baenziger, S., Carter, A., Korzun, V., Morrell, P. L., Dubcovsky, J., Morell, M. K., Sorrells, M. E., Hayden, M. J., and Akhunov, E. 2013. Genome-wide comparative diversity uncovers multiple targets of selection for improvement in hexaploid wheat landraces and cultivars. Proc. Natl. Acad. Sci. USA 110:8057-8062.

Fetch, T., Zegeye, T., Singh, D., Wanyera, R., Penner, M., and Rashid, K. 2012. Virulence of Ug99 (race TTKSK) and race TRTTF on Canadian wheat cultivars. Can. J. Plant Sci. 92:602. 
Fox, S. L., Townley-Smith, T. F., Thomas, J. B., Humphreys, D. G., Brown, P. D., McCallum, B. D., Fetch, T. G., Menzies, J. G., Gilbert, J. A., Fernandez, M. R., Gaudet, D. A., and Noll, J. S. 2010. Harvest hard red spring wheat. Can. J. Plant Sci. 90:503-509.

Guerrero-Chavez, R., Glover, K. D., Rouse, M. N., and Gonzalez-Hernandez, J. L. 2015. Mapping of two loci conferring resistance to wheat stem rust pathogen races TTKSK (Ug99) and TRTTF in the elite hard red spring wheat line SD4279. Mol. Breed. 35:8.

Hiebert, C. W., Fetch, T. G., Zegeye, T., Thomas, J. B., Somers, D. J., Humphreys, D. G., McCallum, B. D., Cloutier, S., Singh, D., and Knott, D. R. 2011. Genetics and mapping of seedling resistance to Ug99 stem rust in Canadian wheat cultivars 'Peace' and 'AC Cadillac'. Theor. Appl. Genet. 122:143-149.

Hiebert, C. W., Kassa, M. T., McCartney, C. A., You, F. M., Rouse, M. N., Fobert, P., and Fetch, T. G. 2016. Genetics and mapping of seedling resistance to Ug99 stem rust in winter wheat cultivar Triumph 64 and differentiation of SrTmp, SrCad, and Sr42. Theor. Appl. Genet. 129:2171-2177.

Jin, Y., Singh, R. P., Ward, R. W., Wanyera, R., Kinyua, M., Njau, P., Fetch, T., Pretorius, Z. A., and Yahyaoui, A. 2007. Characterization of seedling infection types and adult plant infection responses of monogenic $\mathrm{Sr}$ gene lines to race TTKS of Puccinia graminis f. sp. tritici. Plant Dis. 91:1096-1099.

Knott, D. R., and Shen, I. S. 1961. The inheritance of resistance to races 15B and 56 of stem rust in eleven common wheat varieties of diverse origin. Can. J. Plant Sci. 41:587-601.

Kolmer, J. A., Dyck, P. L., and Roelfs, A. P. 1991. An appraisal of stem and leaf rust resistance in North American hard red spring wheat and the probability of multiple mutations to virulence in populations of cereal rust fungi. Phytopathology 81:237-239.

Kosambi, D. D. 1943. The estimation of map distances from recombination values. Ann. Eugen. 12:172-175.

Lorieux, M. 2012. MapDisto: fast and efficient computation of genetic linkage maps. Mol. Breed. 30:1231-1235.

McIntosh, R. A. 1972. Cytogenetical studies in wheat VI. Chromosome location and linkage studies involving $\mathrm{Sr} 13$ and $\mathrm{Sr} 8$ for reaction to Puccinia graminis f. sp. tritici. Aust. J. Biol. Sci. 25:765-773.

Olivera, P. D., Jin, Y., Rouse, M., Badebo, A., Fetch, T., Singh, R. P., and Yahyaoui, A. 2012. Races of Pucinnia graminis f. sp. tritici with combined virulence to $\mathrm{Sr} 13$ and $\mathrm{Sr} 9 \mathrm{e}$ in a field stem rust screening nursery in Ethiopia. Plant Dis. 96:623-628.
Peturson, B. 1958. Wheat rust epidemics in western Canada in 1953, 1954, and 1955. Can. J. Plant Sci. 38:16-28.

Pretorius, Z. A., Singh, R. P., Wagoire, W. W., and Payne, T. S. 2000. Detection of virulence to wheat stem rust resistance gene Sr31 in Puccinia graminis f. sp. tritici in Uganda. Plant Dis. 84:203.

Röder, M. S., Korzun, V., Wendehake, K., Plaschke, J., Tixier, M., Leroy, P., and Ganal, M. W. 1998. A microsatellite map of wheat. Genetics 149: 2007-2023.

Rouse, M. N., Nirmala, J., Jin, Y., Chao, S., Fetch, T. G., Pretorius, Z. A., and Hiebert, C. W. 2014. Characterization of $\mathrm{Sr} 9 \mathrm{~h}$, a wheat stem rust resistance allele effective to Ug99. Theor. Appl. Genet. 127:1681-1688.

Rouse, M. N., Wanyera, R., Njau, P., and Jin, Y. 2011. Sources of resistance to stem rust race Ug99 in spring wheat germplasm. Plant Dis. 95:762-766.

Singh, R. P., and McIntosh, R. A. 1986. Cytogenetical studies in wheat XIV. $\mathrm{Sr} 8 \mathrm{~b}$ for resistance to Puccinia graminis tritici. Can. J. Genet. Cytol. 28: 189-197

Somers, D. J., Isaac, P., and Edwards, K. 2004. A high density microsatellite consensus map for bread wheat (Triticum aestivum L.). Theor. Appl. Genet. 109:1105-1114.

Sourdille, P., Singh, S., Cadalen, T., Brown-Guedira, G. L., Gay, G., Qi, L., Gill, B. S., Dufour, P., Murigneux, A., and Bernard, M. 2004. Microsatellite-based deletion bin system for the establishment of geneticphysical map relationships in wheat (Triticum aestivum L.). Funct. Integr. Genomics 4:12-25.

Stakman, E. C., Stewart, D. M., and Loegering, W. Q. 1962. Identification of physiologic races of Puccinia graminis var. tritici. U.S. Dep. Agric.-Agric. Res. Ser. E617.

Thomas, J., Chen, Q., and Howes, N. 1997. Chromosome doubling of haploids of common wheat with caffeine. Genome 40:552-558.

Wang, S., Wong, D., Forrest, K., Allen, A., Chao, S., Huang, B. E., Maccaferri, M., Salvi, S., Milner, S. G., Cattivelli, L., Mastrangelo, A. M., Whan, A., Stephen, S., Barker, G., Wieseke, R., Plieske, J., International Wheat Genome Sequencing Consortium, Lillemo, M., Mather, D., Appels, R., Dolferus, R., Brown-Guedira, G., Korol, A., Akhunova, A. R., Feuillet, C., Salse, J., Morgante, M., Pozniak, C., Luo, M., Dvorak, J., Morell, M., Dubcovsky, J., Ganal, M., Tuberosa, R., Lawley, C., Mikoulitch, I., Cavanagh, C., Edwards, K. J., Hayden, M., and Akhunov, E. 2014. Characterization of polyploidy wheat genomic diversity using a high-density 90000 single nucleotide polymorphism array. Plant Biotechnol. J. 12:787-796. 